九州大学学術情報リポジトリ

Kyushu University Institutional Repository

\title{
PERMIAN FUSULINIDS FROM THE KITAKAMI MOUNTAINLAND, NORTHEAST JAPAN
}

Tor iyama, Ryuzo

Faculty of Sciences, Kyushu University

https://doi.org/10.5109/1524105

出版情報：九州大學理學部紀要：Series D, Geology. 3 (3)，pp.127-156，1952-05-10. Faculty of Science, Kyushu University バージョン :

権利関係 : 


\title{
PERMIAN FUSULINIDS FROM THE KITAKAMI MOUNTAINLAND, NORTHEAST JAPAN
}

\author{
By
}

\author{
Ryuzo TORIYAMA
}

(Received November 30, 1951)

Several years have passed since Professor M. Minato of Hokkaido University asked me to study his collection of the Permian fusulininds collected from the southern part of the Kitakami Mountainland, Northeast Japan. Meanwhile the Paleozoic stratigraphy of the area has been much clarified (Minato, 1942. 1944A-C), being the most typical display of the Paleozoic succession in this country; and it is desirable to publish the paleontological study on fusulinids of this area in the light of precise knowledge of recent micropaleontology.

Unfortunately, however, almost all of the specimens in Minato's collection are by no means in a favourable condition of preservation; furthermore some of them were clearly deformed after fossilization, being compressed or prolonged along a direction almost perpendicular to that of pressure due to the crustal movements. It is, therefore, understood without difficulty that they might originally have had more thick form than they have now, or vice versa. In the study of fusulinid foraminifera the external form of shell and form ratio are important criteria for the specific determination. Accordingly it is clear that the deformation of fossil specimens is much in the way of specific determination. Before being deformed by pressure, what original feature each individual had may be related to many such factors as the magnitude of pressure, competency of rock in which the fossil specimen was contained, grade of fossilization, structure of animal body, in what direction the fossil animal was laid or embedded by the direction of pressure, and so on. Under the present knowledge of micropaleontology, however, we are not able to restore the deformed 
specimen to its original feature. Therefore I have dealt with all the specimens as they are without any restoration.

Although the material available to me is inadequate for a precise paleontological study, I gave, neverthless, a preliminary report on the Kitakami fusulinids at the 54th Annual Meeting of the Geological Society of Japan in 1947, in which I listed thirty species including seven new species. However, I am now of the opinion that the establishment of new species should be based on more and better preserved specimens. Therefore, new species in my preliminary report should be left as nomina nuda, otherwise they may cause future confusion.

As a result of this study I have distinguished twenty-five species of eleven genera as listed in the table inserted here. Of which Lepidolina? gigantea will be described separately in another paper which is now in printing. (see references)

So far as the Permian fusulinids are concerned the fossil zones in the Kitakami Mountainland have been divided into the lower Pseudoschwagerina- and the upper Yabeina-zones, and the middle Parafusulina-zone has been added recently.

To correlate these zones with the fusulinid zones of other part of the world is rather difficult, because I am not able to discuss in much detail all the species described in this paper which have not been determined with confidence. Judging from the faunal assemblage in general, however, the stratigraphic age of the horizons here designated Pseudoschwagerina-zone seems to be not restricted to the Sakmarian or to the Wolfcampian, but some of them may probably be ranging up at least to early Artinskian or to Leonardian. In other words, they are comprised of fusulinid fauna characteristic rather of the Parafusulina-zone, and should be designated Parafusulina-zone, which is almost equivalent to the Leonardian of North America.

According to Minato (1944A) species of Yabeina are reported from the upper Kohama and the middle Iwaizaki stages of Kanokura Series, but I am not able to mention to which stage each Yabeina-limestone discussed in this paper belongs. ${ }^{1)}$ From the paleontological point of view, however, the neoschwagerinids

\footnotetext{
1) I am very sorry that I have never been in the area under consideration, and the determination of horizon for all limestones in the inserted table was made by personal information from Professor Minato.
} 
contained in the Yabeina-limestones of the area are considered to be the most highly specialized representatives, displaying the phyllogerontic stage of this family. Therefore, the stratigraphic age of Yabeina-zone containing such highly developed forms of Lepidolina? as L. gigantea Toriyama and L.? spp. is considered to be the youngest among the fusulinid zones in the Kitakami Mountainland, which may correspond to the late Cache Oreek, and seem to be better designated the Lepidolina?-zone.

Locality and Depository. The localities from which fusulinids described or discussed in this paper were obtained are in Kesengun, Iwate Prefecture, Northeast Japan. More detailed locality names are described in the inserted table and in the description of species.

All of the illustrated specimens of species described in this paper will be deposited in the Paleontological Collection of Hokkaido Universty at Sapporo, Hokkaido.

Acknowledgments. This study was carried out mainly in Kyushu University, and partly in the University of Wisconsin while I was in Madison, Wisconsin.

I wish to express my sincere thanks to Professor M. Minato of Hokkaido University for the opportunity to study his collection, and to Professor M. L. Thompson of the University of Wisconsin for kind criticism of this study, and to Doctor E. BENJAMIN of Kyushu University for his kindness of reading over my manuscript.

The financial assistance for this study was granted through the Scientific Research funds given by the Department of Education of the Japanese Government, and through the Research Committee of the University of Wisconsin from funds furnished by the Wisconsin Alumni Research Foundation. I thank both of them.

\section{SYSTEMATIC PALEONTOLOGY FAMILY FUSULINIDAE SubFamily OZAWAINELlinaE \\ Genus MILlERELLA Thompson, 1942}

Millerella? sp.

Pl. III, fig. 1

Minute lenticular species of three and half volutions with more or less subangular periphery, gently convex lateral slopes 
and depressed polar areas. Peripheral angles are about 70 degrees. The axial length is the shortest diameter of the shell, having an axial length of about $0.18 \mathrm{~mm}$ and a diameter of about $0.50 \mathrm{~mm}$. Form ratio being 0.4 . The ratios of the half length to the radius vector of the first to the third volution of the figured specimen are $0.6,0,6$ and 0.6 , respectively.

The proloculus is very minute and is round, having an outside diameter of 60 microns. The wall thickness of the proloculus is 10 microns. The inner two volutions are completely involute, but the third volution becomes slightly evolute and the last half volution is absolutely evolute. The half axial lengths of the first to the third volution of the figured specimen are $0.04,0.08$, and $0.13 \mathrm{~mm}$, respectively. The radius vectors of the first to the third volution of the same specimen are $0.07,0.13$, and $0.23 \mathrm{~mm}$, respectively.

The spirotheca is very thin and apparently composed of only a single homogenous layer, though some parts of the spirotheca are thickened by the secondary deposits. The spirothecal thickness cannot be measured exactly, except in the first volution where it attains a thickness of 19 microns.

Chomata and tunnel are not defined, except in the first volution where the very obtuse tunnel-like depression can be seen. The septa are unfluted throughout the length of the shell.

Remarks. - In having characteristic evolute outer volutions and narrowly rounded periphery it is most probable that the present species is referred to the genus Millerella. However no species of the said genus has been reported from the Permian Rocks of Japan. Although it may be considered that the genus Millerella ranges up to the Permian it is not impossible to regard this specimen as a derived fossil, because this specimen is contained in small subangular limestone piece, and the limestone is more or less conglomeratic as a whole. It needs much more materials and further study to describe this species in detail and to determine the age of the species. [I am not clear from a doubt that the thin slide (302-1) in which the present specimen is contained has been mislabeled, because there are much differences in the state of preservation and in the texture of limestone between the thin slide under consideration and others labeled in same locality number.] 


\begin{tabular}{|c|c|c|c|c|c|c|c|c|c|c|c|c|c|c|c|c|c|c|c|}
\hline Specific & ne and & 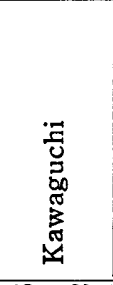 & 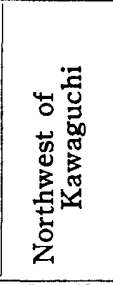 & & 苋 & & 选 & & & 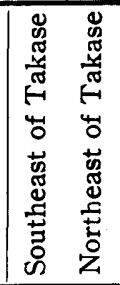 & & 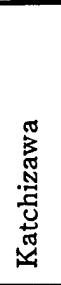 & & 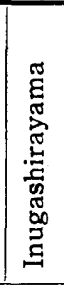 & 总 & 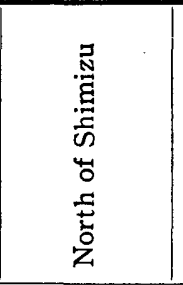 & 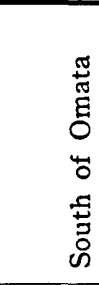 & है & 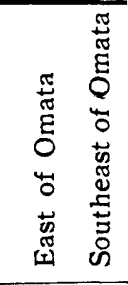 \\
\hline Stratig & hic horizon & 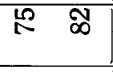 & 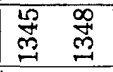 & $\sqrt{2}$ & 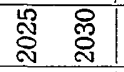 & 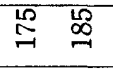 & $\stackrel{\infty}{\infty}$ & $\stackrel{\mathscr{N}}{N}$ & 总 芯 & 今心 & 焉 & 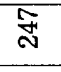 & है & $\underset{0}{0}$ & 文 & 总 & $\begin{array}{l}0 \\
\stackrel{N}{N} \\
\end{array}$ & 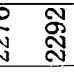 & 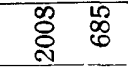 \\
\hline Horizon & $\begin{array}{l}\text { Yabeina-limestone } \\
\text { Pseudoschwagerina-limestone }\end{array}$ & 0 & - 0 & $\bullet$ & 0 & ○? & & O & 00 & & 0 & 0 & 0 & ? & - & $\bullet \bullet ? \bigcirc ?$ & - & 0 & $\dot{0}^{0 ?}$ \\
\hline $\begin{array}{l}\text { 1. } \text { Mille } \\
\text { 2. Staffe } \\
\text { 3. Waer }\end{array}$ & $\begin{array}{l}\text { la sp. } \\
\text { yobarensis Ozawa } \\
\text { zella? sp. }\end{array}$ & & & & & $x$ & & & & & & $x$ & $x$ & & $\bullet$ & & & & \\
\hline $\begin{array}{l}\text { 4. Sippc } \\
\text { 5. Schw } \\
\text { 6. Schw } \\
p s e t \\
\text { 7. Schw } \\
\text { 8. Schw } \\
\text { 9. Schw } \\
\text { 10. Schwc }\end{array}$ & $\begin{array}{l}\text { telia } \text { sp. } \\
\text { rina douvillei (Colani) } \\
\text { rina cfr. guembeli var. } \\
\text { regularis Dundar and Skinner } \\
\text { rina sp.? A } \\
\text { sp.? B } \\
\text { rina sp.? C } \\
\text { sp. indet. }\end{array}$ & $x$ & $\mid \begin{array}{cc}x & x \\
x & \end{array}$ & & & $\begin{array}{l}x \\
x \\
x\end{array}$ & & & $x$ & & $x$ & & $x$ & $\times ?$ & & \begin{tabular}{ll|}
$\times$ & \\
& $\times ?$
\end{tabular} & $x$ & & $\times ?$ \\
\hline $\begin{array}{l}\text { 11. Pseud } \\
\text { 12. Acert }\end{array}$ & $\begin{array}{l}\text { chwagerina? sp. } \\
\text { chwagerina? sp. }\end{array}$ & & & & & & & & & $x$ & & & & & $x$ & & & & \\
\hline $\begin{array}{l}\text { 13. Paraf } \\
\text { 14. Puraf } \\
\text { 15. Paraf } \\
\text { 16. Puraf }\end{array}$ & $\begin{array}{l}\text { ulina cfr. wanneri (Schubert) } \\
\text { ulina cfr. kattacnsis (Schwager) } \\
\text { lina cfr. gigantea (Deprat) }\end{array}$ & $\times \quad \times$ & $x$ & $\begin{array}{l}\times \\
\times\end{array}$ & $\begin{array}{r} \\
\times \\
\times ?\end{array}$ & $x$ & & $x$ & $x$ & $x$ & & & $x$ & & $x$ & $\times ?$ & $\begin{array}{r}\times \\
\times \quad \times\end{array}$ & $\begin{array}{l}x \\
\times \\
x\end{array}$ & $x$ \\
\hline $\begin{array}{l}\text { 17. Pseud } \\
\text { 18. Pseud } \\
\text { wata } \\
\text { 19. Pseud }\end{array}$ & $\begin{array}{l}\text { isulina cfr. japonica (Gümbel) } \\
\text { usulina cfr. vulgaris var. } \\
\text { bei (Ozawa em. Lee) } \\
\text { usulina } \text { sp. }\end{array}$ & & $x$ & & $x$ & $x$ & & & & & & & $x$ & & & $x$ & $x$ & & \\
\hline $\begin{array}{l}\text { 20. Pseud } \\
\text { 21. Lepid } \\
\text { 22. Lepid } \\
\text { 23. Lepid } \\
\text { 24. Lepid } \\
\text { 25. Lepid }\end{array}$ & $\begin{array}{l}\text { oliolina? sp. } \\
n a \text { ? gigantea Toriyama } \\
n a \text { ? sp. A } \\
n a \text { ? sp. B } \\
n a \text { ? sp. C } \\
n a \text { ? sp. D }\end{array}$ & & & & & $\begin{array}{l}\times \\
\times \\
x\end{array}$ & $\begin{array}{l}x \\
\times\end{array}$ & & $\begin{array}{l}x \\
x\end{array}$ & & $x$ & $x$ & $\begin{array}{l}x \\
x\end{array}$ & & & & & & $x$ \\
\hline
\end{tabular}


Locality and Horizon - This species occurs in the Yabeinalimestone of Katchizawa (Loc. 302), Setamai-mura, associating with Schwagerina douvillei (Colani), Parafusulina cfr. wanneri (Schubert), Pseudofusulina sp., and Lepidolina? spp.

\section{Genus STAFFElla Ozawa, 1925 \\ Staffella Yobarensis Ozawa}

Pl. III, fig. 2

1925. Staffella yobarensis Ozawa. Paleontological and stratigraphical Studies on the Permo-Carboniferous Limestone of Nagato, Part II, Paleontology. Jour. Coll. Sci. Imp. Univ. Tokyo, Vol. XLV, Art. 6, p. 20 Pl. III, figs. lb, 5.

Shell is small and subspherical, with a length of about $1.00 \mathrm{~mm}$ and a diameter of $1.3 \mathrm{~mm}$. Axis of coiling is the shortest diameter. The number of volutions is 6 . The half lengths of the first to the sixth volution of the figured specimen are $0.08,0.12$, $0.17,0.26,0.38$, and $0.51 \mathrm{~mm}$, respectively. The ratios of the half length to the radius vector of the first to the sixth volution of the same specimen are $0.7,0.6,0.6,0.6,0.7$, and 0.8 , respectively.

The proloculus is very small and somewhat irregular in shape. The size of the proloculus, though not well measured, is approximately 120 microns in an outside diameter. The inner three volutions are subelliptical, their axial diameter being only two-thirds to half of the equatorial diameter, and in the outer volutions the periphery broadens as the shell grows. The radius vectors of the first to the sixth volution of the figured specimen are $0.11,0.20$, $0.30,0.41,0.55$, and $0.64 \mathrm{~mm}$, respectively.

The spirotheca is thin, measuring about 14 microns in the third, 19 microns in the fourth, and increasing to 23 microns in the fifth and sixth volutions. The spirotheca seems to be replaced by the secondary mineralization and is hard to determine its minute structure. Chomata are low and rather obscure, especially so in outer volutions. Septa are not fluted.

Remarks — In the present material few specimens referred to this species are contained, but all of them except one which is illustrated as Pl. III, fig. 2 are too poorly preserved and cut excentrically, and are not available for illustration nor measurements.

Staffella yobarensis was decribed by Ozawa from Yobara, Akiyoshi Limestone, Yamaguchi Prefecture. In external configura- 
tion and inner characters of the shell the present form well agrees with those of the Akiyoshi form, except in the size of shell and a little heavier chomata in the latter. According to Ozawa's original description $S$. yobarensis has a length of $0.25-0.30 \mathrm{~mm}$ and a diameter of $0.31 \mathrm{~mm}$, while those of the present form are $1.0 \mathrm{~mm}$ and $1.3 \mathrm{~mm}$, respectively. It must be noted, however, that there is considerable discrepancy between Ozawa's description and his illustration. The axial length and diameter of Ozawa's form measured from his microphotograph are $0.84 \mathrm{~mm}$ and $0.98 \mathrm{~mm}$, respectively. If the latter are correct there is not a remarkable enough difference in the size of the shell as to distinguish the species bctween Akiyoshi and the present forms.

Locality and Horizon- - In Akiyoshi Limestone Staffella yobarensis was reported from Ozawa's $\mathrm{P}_{2}$. He described the following species from Yobara as Triticites yobarensis (OzawA), Schwagerina krotowi (Schellwien), Paraschwagerina oblonga (Ozawa), Parafusulina edoensis (Ozawa), Pseudofusulina ambigua (DDprat), and Verbeekina verbeeki GeInItz. However, it seems that these species occur not in one locality, but several ones around Yobara, Beppumura.

In the Kitakami Mountainland this species occurs from Loc. 247 of the Yabeina-limestone of Katchizawa, Setamai-mura, associating with Pseudodoliolina? sp.

\author{
SubFAMILY SCHUBERTELLINAE \\ Genus WAERingella Thompson, 1942 \\ Waeringella? sp. \\ Pl. III, figs. 3,4
}

A rather small, slender fusiform shell, attaining 8 to 10 volutions, with more or less uneven lateral slopes and narrowly rounded ends. A half length and a half diameter of shell having 8 volutions are $2.7 \mathrm{~mm}$ and $0.85 \mathrm{~mm}$, respectively. The ratios of the half length to the radius vector of the first to the eighth volution of the figured axial section are $2.9,3.0,4.0,3.4,3.5,3.4$, 3.4 , and 3.2, respectively. The half lengths of the first to the eighth volution of the same specimen are $0.26,0.41,0.77,0.95$, $1.36,1.70,2.25$, and $2.70 \mathrm{~mm}$, respectively.

The proloculus is small and spheric, attaining an outside 
diameter of about 120 microns. The inner five or six volutions are rather closely coiling, but the outer volutions expand considerably more rapidly. The radius vectors of the first to the eighth volution of the figured axial section are $0.09,0.14,0.19$, $0.27,0.39,0.50,0.66$, and $0.85 \mathrm{~mm}$, respectively, and those of the first to the tenth volution of the figured sagittal section are 0.09 , $0.13,0.17,0.22,-,-, 0.51,0.59,0.75$, and $0.93 \mathrm{~mm}$, respectively.

The spirotheca is thin and seems to be composed of two layers, although it is hard to observe its minute structure, being metamorphosed. However, no keriothecal structure can be observed. The thickness of the keriotheca increases from 19 microns in the first to 70 microns in the tenth volution. The average spirothecal thicknesses of the third to the seventh volution of three specimens are $28,28,28,33$, and 35 microns, respectively.

The septa are almost plane, except in both polar regions where they flute weakly. The chomata are very heavy and are well developed throughout whole volutions. The tunnel is moderately wide. Tunnel angles are almost uniform, attaining 35 degrees at the second and 37 degrees at the last volution.

Remarks - Although few specimens of Waeringella? sp. have been found in the collection, it is regrettable that there is no exactly oriented section. As the specimens were considerably metamorphosed, the minute structures of the spirotheca are hardly discernible. It seems, however, that the species had originally no keriothecal structure in the spirotheca, because some specimens of Schwagerina sp. contained in the same slide display clear keriothecal structure in the spirotheca.

Because of the poor state of preservation and the insufficiecy of material I am referring the species to Waeringella with some doubt. If this species is definitely a species of Waeringella, this is the first occurence of the said genus in Japan.

Locality and Horizon - Waeringella? sp. has been found in the Loc. 175 of the Pseudoschwagerina-limestone of Kanokurazawa, Setamai-mura, assocaited with Nipponitella sp., Schwagerina cfr. guembeli var. pseudoregularis Dunbar and Skinner, Schwagerina sp. B, Parafusulina cfr. wanneri (SchuBerT), and Pseudofusulina cfr. japonica (GumBeL). 


\section{Subfamily SCHWAGERININAE \\ Genus NipPONITElla Hanzawa, 1938 \\ Nipponitella $s$ p. \\ P1. III, fig. 5}

Several specimens of irregular forms of Nipponitella have been obtained from Kanokurazawa. It is a matter of regret, however, that as most of them are poorly preserved and are not well oriented, it is not possible to determine all the characters of this form. For the sake of completeness I am illustrating one of this form.

Shell moderate in size. Subcylindrical or ellipsoidal juvenility is composed of three or four volutions, attaining a length of about 3-4 mm and a diameter of about $1.2-1.5 \mathrm{~mm}$. The uncoiling of the shell takes place at the fourth or the fifth volution, developing the terminal flange of $1.1 \mathrm{~mm}$ or more in thickness. Width of terminal flange cannot be measured exactly, but it is not less than $3.2 \mathrm{~mm}$. The average radius vectors of the first to the fourth volution of five specimens are $0.28,0.40,0.59$, and $0.84 \mathrm{~mm}$, respectively.

The spirotheca seems to be composed of a tectum and a keriotheca, in which minute structure is hardly observable. The spirotheca is rather thin, attaining a thickness of $47,47,56-61$, and 70-92 microns in the first to the fourth volution of two specimens.

The septa are rather weakly fluted in the median portion of the juvenility, but intensely and regularly in the polar regions; in the terminal flange they are also intensely fluted.

Chomata are present in the juvenarium. Tunnel angle is 55 degrees at the third volution.

Remarks - Although the present material is not enough for specific determination, this form seems to be a new species of Nipponitella. However the assignment of the new specific name for this form should be deferred until additional and better specimens are obtained.

Locality and Hovizon - This species has been obtained from Loc. 175 of Pseudoschwagerina-limestone of Kanokurazawa, Setamaimura, associating with Waeringella? sp. Schwagerina cfr. guembeli var. pseudoregularis Dunbar and SkInNer; Schwagerina sp. B, 
Parafusulina cfr. wanneri (Schubert) and Pseudofuslina cfr. japonica (Gïmbel).

Genus SCHWAGERINA Möller, 1877

Schwagerina douvillei (CoLANI)

P1. III, figs. 6-8

1924. Fusulina douvillei Colan. Nouvelle contribution a l'étude des Fusulinides de l'extreme Orient. Mém. Serv. Géol. l'Indochine, Vol. 2, fasc. 1, pp. 98, 99. Pl. X, figs. 5, 25, Pl. XIII, figs. 2-26.

1937. Schwagerina douvillei Huzmoto. Some Fusulinids from Kawanobori-mura, Kyushu, Japan. Jap. Jour. Geol. Geogr. Vol. XIV, pp. 122, 123. P1. 7, figs. $12,13$.

A rather small, short fusiform species of seven or eight volutions, attaining a length of about $6.5 \mathrm{~mm}$ and a diameter of $3.5 \mathrm{~mm}$. Shell has a short cylindrical form of the middle portion from which gently convex lateral slopes extend to the narrowly rounded poles. As the shell takes almost the same feature during the growth, the form ratio changes but little. The half axial length of the third, fifth to the eighth volution of the figured axial section are $0.70,1.26,1.78,2.36$, and $3.14 \mathrm{~mm}$, respectively. The ratios of half length to the radius vector of the same specimen are 2.0 in the third, and 1.8 in the outer four volutions.

The proloculus is small and spheric. An outside diameter of it ranges from 160 to 250 microns, averaging 210 microns in three specimens. Shell expands rather tightly and gradually in the inner four or five volutions, but becomes rapid and almost uniform in the outer ones. Averages of radius vector of the first to the seventh volution of three specimens are $0.15,0.23,0.33,0.47,0.69$, 0.96 , and $1.29 \mathrm{~mm}$, respectively.

The spirotheca consists of a tectum and well-defined keriotheca. About 26 alveoli occupy a space of $0.50 \mathrm{~mm}$ in the lower keriotheca, whereas one or occasionaly two of very short alveoli develop between each pair of the longer alveoli in the upper keriotheca. This feature can be observed especially well in the outer volutions. As a whole spirotheca is rather thin. Average combined thicknesses of tectum and keriotheca of the first to the sixth volution in two specimens are $31,36,36,47,66$, and 78 microns, respectively.

The septa, composed of dense pyknotheca, are about as thick as the spirotheca in the inner volutions and are a little thinner in 
the outer ones. Average septal counts of the first to the fifth volution of two specimens are $9,19,20,22$, and 24 , respectively. The septa are strongly and regularly fluted, but no cuniculus is present in the tangential section. Chomata do not develop, but axial fillings are well developed in the axial zones of the inner volutions.

Remarks - - Although the materials at my disposal are insufficient in number, they are one of the best preserved specimens in the present collection.

This form well agrees with Schwagerina douvillei (CoLANI) in the external shape, rate of growth, the thinness of spirotheca, and septal counts. However, the median portion of the present form is a little more cylindrical in shape and the proloculus is more or less larger in size.

In Japan Schwagerina douvillei was described by Huzıмoтo from the Paleozoic Chichibu Complex of Kawanobori-mura, Oita Prefectnre, Kyushu. Comparing the present form with Kyushu's form, there is a little difference between them, that is to say, the present form has more numerous volutions, a little larger proloculus, and no chomata.

This form also resembles Schwagerina guembeli Dunbar and SkinNer, but is distinguished from the latter in the size of shell, number of volutions, and the size of proloculus.

Locality and Horizon - Schwagerina douvillei (Colani) has been found in the Loc. 302 of the Yabeina-limestone of Katchizawa, Setamai-mura. Associating species are Millerella? sp., Parafusulina cfr. wanneri (Schubert), Pseudofusulina sp., and Lepidolina? spp.

Schwagerina cfr. guembeli var. pseudoregularis

Dunbar and Skinner

Pl. III, figs. 9, 10

1937. Schwagerina guembeli var. pseudoregularis Dunrar and SKInNer. Permian Fusulinidae of Texas. Univ. Texas Bull. 3701, pp. 640-641. PI. 61, figs. 14-24.

The shell has elongate ellipsoidal shape of 5 to 7 volutions, attaining a length of $8.5 \mathrm{~mm}$ and a diameter of $2.7 \mathrm{~mm}$, the form ratio being between 2.6 and 3.2. The polar ends are neatly rounded.

The proloculus is of moderate size, thin-walled, and spheric or somewhat flattened, having an outside diameter ranging from 
220 to 370 microns. The volution expands slowly in the first two or three volutions, then the expansion becomes rapid and almost uniform. The average radius vectors of the first to the sixth volution in eight specimens are $0.18,0.32,0.46,0.68,0.84$, and $1.08 \mathrm{~mm}$, respectively.

The spirotheca consists of a tectum and a keriotheca. The average thicknesses of the spirotheca of the first to the sixth volution in four specimens are $30,42,44,59,77$, and 87 microns, respectively.

The septa are strongly fluted in both polar regions, forming septal loops in the axial sections, while they are rather weakly fluted in the median portion of the shell. There is no trace of chomata. The tunnel angle is about 25 degress in the outer volutions, though it cannot be measured exactly. The secondary deposits are developed in the axial zones of the inner few volutions.

Remarks - Although I have not been able to observe exactly well-oriented sections in the specimens at my disposal, the present form is most closely allied to Schwagerina guembeli var. pseudoregularis Dunbar and SkinNer, so far as the form of shell, the thickness of the spirotheca, and the characters of the septal fluting are concerned. Strictly speaking, however, there is a little difference between them; that is to say, the present form has a more or less slender form of the shell and a little larger proloculus. Locality and Horizon - In Texas S. guembeli var. pseudoregularis occurs with $S$. guembeli s. str. in the Leonard formation of Glass Mountain. In the Kitakami Mountainland this species has been found in the Pseudoschwagerina-limestone. Localities and associated species are as follows;

Loc. 1345, Northwest of Kawaguchi, associated with Schwagerina sp. A and Pseudofusulina cfr. vulgaris var. watanabei (OzAwA em. LEE); Loc. 1348, Northwest of Kawaguchi, associated with Parafusulina cfr. wanneri (Schubert); and Loc. 175, Kanokurazawa, associated with Waeringella? sp., Nipponitella sp., Schwagerina sp. B, Parafusulina cfr. wanneri (Schubert), and Pseudofuslina cfr. japonica (Gümbel). All the localities are in Setamai-mura. 


\section{Schwagerina? sp. A}

P1. III, fig. 11

As this form is represented by only a single para-axial section which is more or less deformed, it is difficult to identify the species.

External configuration is probably short cylindrical, with straight median portion and rounded polar ends. The shell seems to have a length of at least $3.3 \mathrm{~mm}$ and a width of $1.2 \mathrm{~mm}$, the form ratio being 2.7. Volution numbers 4 .

The proloculus is subspheric in shape, with an outside diameter of 140 microns. The first volution is closely coiled. From the second volution the shell expands rather rapidly. The radius vectors of the first to the fourth volution are $0.11,0.16,0.28$, and $0.59 \mathrm{~mm}$, respectively.

The spirotheca seems to consist of a tectum and a keriotheca. Because of the poor state of preservation their minute structures are hardly observable even under high magnification. As a whole the spirotheca is thin, attaining a thickness of 33,33 , and 38 microns, respectively, in the first to the third volution.

The septa is also thin, and is fairly strongly fluted throughout the length of shell. There is no trace of chomata and axial fillings.

Remarks — So far as its growth-rate and thin spirotheca are concerned, there is no species in the genus Schwagerina to which the present one is closely allied, although it may be possible that the present form represents a submature individual of some species.

Locality and Horizon - This species occurs in the Pseudoschwagerina-limestone of the northwest of Kawaguchi, Setamaimura, associated with Schwagerina cfr. guembeli var. pseudoregularis Dunbar and SkInNer and Pseudofusulina cfr. vulgaris var. watanabei (Ozawa em. LEE). Locality number is 1345.

Schwagerina? sp. B

Pl. III, fig. 12

This species is represented by only one axial (slightly oblique) and a few oblique sections, so I have been unable to observe all the characteristics sufficiently. 
The shell small, inflated fusiform, straight axis of coiling, more or less rounded poles, attaining a length of $4.9 \mathrm{~mm}$ and a width of $2.5 \mathrm{~mm}$. The form ratio being 2.0 . The volution numbers 5 .

The proloculus seems to be spheric, in shape and to have an outside diameter of 260 microns or more, though it cannot be measured exactly. The shell expands rather slowly. The radius vectors of the first to the fifth volution of the figured axial section are $0.20,0.33,0.55,0.85$, and $1.25 \mathrm{~mm}$, respectively.

The spirotheca is moderate in thickness, consisting of a thin tectum and a more or less thick keriotheca. Alveolar structure of the latter is well defined except in the inner two volutions where it is not distinct, probably because of the poor state of preservation. Thicknesses of the spirotheca of the second to the fifth volution are 50, 85, 94, and 94 microns, respectively.

Septal fluting is rather intense except in the median portions of each volution where it is weak. Septal count unknown. Chomata seem to be present in the outer few volutions. No axial filling is present.

Remarks - Not enough information is available from the present specimens of Schwagerina? sp. B for specific comparison with other species of this genus described in this paper. In having small size of shell and rudimentary chomata this form is probably a representative of the primitive Schwagerina.

Locality and Horizon — This specics has been found in the Loc. 175 of the Pseudoschwagerina-limestone of Kanokurazawa, Setamaimura, associated with Waeringella? sp., Nipponitella sp., Schwagerina cfr. guembeli var. pseudoregularis Dunbar and SKINNER, Parafusulina cfr. wanneri (SchUвERT), and Pseudofusulina cfr. japonica (GüMBEL).

Schwagerina? sp. C

Pl. IV, figs. 1, 2

Shell is of moderate size, having at least 6 or 7 volutions. Axial length and median width attain at least $6.5 \mathrm{~mm}$ and $2.8 \mathrm{~mm}$, respectively. The form ratio is at least 2.3 or more.

The size and shape of the proloculus are unknown. The shell expands rather slowly and almost uniformly, at least in the outer 
volutions. The average radius vectors of the first to the seventh volution in four specimens are $0.24,0.37,0.48,0.92,1.24$, and $1.49 \mathrm{~mm}$, respectively.

The spirotheca is composed of a tectum and coarsely alveolar keriotheca. The thicknesses of the spirotheca of the third to the fifth volution average 53,61, and 84 microns, respectively, in three specimens.

The septa seem to be fluted rather strongly in both polar regions and moderately in the median portion of the shell.

Chomata are present at least in the outer few volutions. Tunnel angles cannot be measured because of the deformation of the specimens.

Remarks - I have few specimens of this form, and none of them is an oriented section. Moreover, the specimens are very poorly preserved, being deformed after fossilization. It is, therefore, almost hard even to determine the genus. However, so far as the size of the shell, rate of expansion and mode of septal fluting are concerned, this form seems to be distinguished from other species of Schwageriaa? described in this paper.

Locality and Horizon - This form has been found in the following localities as 1) Loc. 252, Kanokurazawa, Setamai-mura, associated with Parafusulina sp.; 2) Loc. 1407, North of Shimizu, Setamai-mura, with Parafusulina cfr. kattaensis (Schwager); and 3) Loc. 2276, South of Omata, Yahagi-mura, with Parafusulia cfr. gigantea (DEPRAT).

Genus PSEUdoschWAgerina Dunbar and Skinner, 1936

Pseudoschwagerina? sp.

Pl. IV, fig. 3

As this form is represented by only a single excentric section and is in extremely unfavourable condition of preservation being almost completely recrystallized, I am not able to observe any important characteristic except the following: Shell seems to have two stages of development. The juvenarium seems to consist of one or two volutions, attaining a diameter of about $1 \mathrm{~mm}$. The inflation following the juvenarium is very rapid, attaining a diameter of about $9 \mathrm{~mm}$ in the last volution. The spirotheca is 
thin in which minute structure can be hardly detected. The septa are also thin and seem to be almost straight.

Remarks - Although I am not sure even of the generic assignment of this form, it may probably be referable to the genus Pseudoschwagerina. So far as the diameter of shell, unfluting septa, and large heights of chamber in the outer volutions are concerned, this form resembles fairly well Pseudoschwagerina schellwieni (YABE) HANZAwA.

Locality and Horizon — This species has been obtained from Loc. 377 of the Pseudoschwagerin-limestone of the southeast of Takase, Setamai-mura, No species associated.

Subgenus ACERVOSCHWAGERINA Hanzawa, 1949

\section{Acervoschwagerina? sp.}

Pl. IV, fig. 4

A few doubtful specimens of Acervoschwagerina? occur in the Psendoschwagerina-limestone of Kotsubo. Almost all of them are preserved in very poor condition, and not well-oriented. I have only observed the following characteristics:

Shell is small, and seems to be composed of one or two tightly coiled juvenarium and two or threc inflated outer volutions. Diameter of juvenarium is 1.5 to $1.9 \mathrm{~mm}$, and that of the last volution is 3 to $4 \mathrm{~mm}$. The spirotheca consists of a tectum and a keriotheca, attaining a moderate thickness of about 80 microns in the outer volutions. Septa flute strongly but somewhat irregularly.

Locality and Horizon - This species has been found in the Loc. 528 of the Pseudoschwagerina-limestone of Kotsubo, Setamai-mura, associated with Parafusulina cfr. kattaensis (Schwager) and Parafusulina sp.

Genus PARAfusulina Dunbar and Skinner, 1931

Parafusulina cfr. wanneri (SchuBERT)

P1. V, fig. 2

1915. Fusulina wanneri Schubert. Die Foraminiferen des jüngeren Paleozoikums von Timor. Paleontolgie von Timor. Lief. 2, Teil 3, pp. 54, 55, Pl. 39(1), fig. 2, Pl. 40(2), fig. 1, Pl. 41(3), figs. 1, 7.

1949. Parafusulina wanneri THompson. The Perian Fusulinids of Timor. Jour. Paleontology, Vol. 23, No. 2, pp. 189-192, Pl. 35, figs. 1-6, Pl. 36, figs. 1-7. 
I have observed several specimens of this form, but none of them is an exactly oriented section. However, for the sake of completeness, I am describing this form, and illustrating one of them.

Axial length and median width of this form varies $11-14 \mathrm{~mm}$ and $1.5-2.0 \mathrm{~mm}$, respectively. Form ratio being 7 or more in mature individuals. Number of volutions may be 5 or more.

The size and shape of the proloculus unknown. The shell seems to expand rather slowly and uniformly. The radius vectors of the fourth and the fifth volutions are measured $0.55-0.66$ and $0.77-1.00 \mathrm{~mm}$, respectively.

The spirotheca is thin, and is composed of a thin tectum and a well-defined keriotheca in which 20 alveoli can be observed in a space of $0.50 \mathrm{~mm}$. The thicknesses of the spirotheca are 70-75 microns in the fourth, and 85 microns in the fifth volution.

The septa seem to be regularly and intensely fluted. The basal foramina and cuniculi are well observed. Numerous fine septal pores are also well developed. Chomata cannot be observed. Remarks - So far as the slender cylindrical form and the dimensions of the shell are concerned it may be presumed that this form is most closely allied to Parafusulina wanneri which was originally described by SchuBERT and was recently restudied in very minute detail by Trompson. It seems that there is no important difference in characteristics between the Timoran form and the present one. However, I hold the identification as tentative until sufficient and better specimens become available.

Locality and Horizon - This species has been obtained from the Yabeina-limestone of Loc. 235 of Kanokurazawa and Loc. 302 of Katchizawa, both in Setamai-mura. In the former it is associated with no species, but in the latter with Millerella? sp., Schwagerina douvillei (Colani), Pseudofuslina sp., and Lepidolina? sp. A, B, C, and $\mathrm{D}$.

\section{Parafusulina cfr. kattaensis (Schwager) \\ Pl. IV, figs. 5, 6, Pl. V, fig. 1}

1885. Fusulina kattaensis Schwagre. Salt Range Fossils. Pal. Indica. pp. 985-987, Pl. 131, figs. 1-5.

1912. Fusulina kattaensis Drprat. Étude des Fusulinides etc. Mém. Géol. l'Indochine, Vol. I., fasc. 3, pp. 31, 32, Pl. IX, figs. 5-11.

1925. Schellwienia cfr. kattaensis Ozawa. Paleontological Studies on the Limestone 
of Nagato. Jour. Coll. Sci. Imp. Univ. Tokyo, Vol. XLV, Art. 6. pp. 21, 22, Pl. VIII, fig. 6b.

1933. Parafusulina kattaensis Dunbar. Stratigraphical Significance of the Fusulinids of the Lower Productus Limestone of the Salt Range. Record Geol. Surv., India. Pt. 4, pp. 408-412, Pl. 22, figs. 1-2j.

Shell elongate subfusiform, probably tapering toward the bluntly rounded poles. The half axial length and half diameter in one specimen measure about $9.2 \mathrm{~mm}$ and $1.4 \mathrm{~mm}$, respectively. The form ratio may be 6.0 or more. Number of volution is at least 5 .

The size and shape of the proloculus are unknown. The shell expands rapidly. The average radius vectors of the first to the fifth volution of four specimens are $0.38,0.57,0.84,1.18$ and 1.51. mm, respectively.

The spirotheca consists of a thin tectum and a well-defined keriotheca, and is rather thin, averaging 56, 92, 102, and 107 microns, respectively, in the second to the fifth volution for three specimens.

The septa seem to be regularly and intensely fluted throughout the length of the shell, although they appear to be irregularly or weakly fluted in some part of shell probably because of deformation. Cuniculi can be observed in the tangential part of the deformed specimens. No phrenotheca nor chomata present.

Remarks - I have been unable to osberve any well-preserved and exactly oriented section in the materials at hand. This form, however, may be referable to Parafusulina kattaensis (Schwager), so far as the dimension of the shell, rate of growth and spirothecal thickness are concerned. $P$. kattaensis of the Salt Range was restudied by Dunbar in detail from which the present form is distinguished by the longer axial length of shell. However, it is unknown that how much the specimens under consideration were prolonged by the deformation after fossilization. In Japrn OzAwA had described this species from the Akiyoshi Limestone, Yamaguchi Prefecture which has smaller size of shell, smaller proloculus and very much thinner spirotheca.

Until sufficient and better specimens become available I hold the specific identification as tentative.

Locality and Horizon - This form has been found in the Pseudoschwagerina-limestone of Loc. 172, Kabayamazawa, Setamai-mura, Loc. 528, Kotsubo, Yokota-mura, and Loc. 1407, North of Shimizu, 
Setamai-mura. The associated species are Parfusulina sp. and Pseudofuslina cfr. japonica (GümBeL) in Loc. 172; Acervoschwagerina? sp. and Parafusulina sp. in Loc. 528; and Schwagerina? sp. C in Loc. 1407.

\author{
Parafusulina cfr. gigantea (DePrAT) \\ Pl. V, figs. 3,4
}

1913. Fusulina gigantea Deprat. Étude des Fusulinidés. Mém. Serv. Géol. d Indochine, Vol. II, fasc. 1, pp. 29, 30, Pl. I, figs. 1-6.

1925. Schellwienia gigantea Ozawa. Paleontological Studies on the Limestone of Nagato. Jour. Coll. Sci. Imp. Univ. Tokyo, Vol. XLV, Art. 6, pp. 32, 33. Pl. IV, fig. 9.

A large species of Parafusulina has been obtained from the Pseudoschwagerina-limestone of Kabayamazawa, Takase and Omata. However, none of them is a well-oriented section or is wellpreserved.

The external configuration of the shell is probably elongate fusiform with rounded poles, attaining a length of about $16 \mathrm{~mm}$ and a width of about $4.2 \mathrm{~mm}$. The volution numbers 5 or more.

The proloculus is of moderate size and spheric, having an outside diameter of 300 microns and a wall thickness of 50 microns. Volution expands rather rapidly and uniformly. The average radius vectors of the first to the fifth volution in four specimens are $0.39,0.65,1.03,1.53$, and $1.93 \mathrm{~mm}$, respectively.

The spirotheca is thick, consisting of a tectum and a thick keriotheca. Minute structure of them is hardly observable except in some part of the outer volutions. The average thicknesses of the spirotheca of the second to the fifth volution in three specimens are $102,129,173$, and 178 microns, respectively.

The septa seem to be intensely fluted throughout the length of shell. Cuniculi are observed in the tangential section. No chomata present.

Remarks — Because of the insufficiency of the material and poor state of preservation the above description and measurements of this form are far from perfect. Notwithstanding this fact, it is highly probably that the present form is closely allied to Parafusulina gigantea (DEPRAT).

$P$. gigantea has been described from Laos (Indo-china) and Akiyoshi by Deprat and Ozawa, respectively. In comparison with 
these forms the present one is intermediate between the Laos form and the Akiyoshi one in the growth rate, thickness of spirotheca, but the proloculus of the present form is the smallest among the threes.

Until sufficient material becomes available I hold the present specific identification as tentative.

Locality and Horizon - This form has been obtained from the Pseudoschwagerina-limestone of 1) Loc. 2025, Kabayamazawa, Setamai-mura, associated with Pseudofusulina cfr. japonica (GümBEL); 2) Loc. 2276 and Loc. 2292, south of Omata, Yahagi-mura, associated with Schwagerina sp. C in the former and Parafusulina cfr. kattaensis in the latter; and 3) 1277, Setamai-mura, with no species.

\section{Parafusulina sp. \\ Pl. V, fig. 5}

I have only one specimen of this form. Although it is a centered axial section, one-third of the shell has been cut off from the slide.

Shell is large and the half of its axial profile is an ogival form, having almost straight median portion, steep lateral slopes, and more or less bluntly rounded pole. The half axial length and half diameter are $4.2 \mathrm{~mm}$ and $2.5 \mathrm{~mm}$, respectively. The form ratio may be about 1.7. The number of volution is 6 .

The spirotheca is of moderate size, having an outside diameter of 560 microns. The shell expands rather rapidly. Radius vectors of the first to the sixth volution are $0.45,0.74,1.11,1.47,1.92$, and $2.47 \mathrm{~mm}$, respectively.

The spirotheca seems to be composed of a tectum and a thick keriotheca, although their minute structure cannot be discernible. The spirothecal thicknesses of the first to the sixth volution are $92,81,112,-, 153$, and 122 microns, respectively. Irregularity in thickness may due to the secondary deposits on the spirotheca.

The septa seem to be intensely and regularly fluted throughout the length of the shell. Chomata not present.

Remarks - As it is impossible to determine all of the characteristics of this form, I am not sure even of the generic identification. However, it differs considerably from other species of 
Parafusulina described in this paper in having a thick fusiform and thick spirotheca.

Locality and Horizon - This form has been found in the Yabeinalimestone of Loc. 252, Kanokurazawa, Setamai-mura, associated with Schwagerina? sp. C.

Genus PSEUdofusulina Dunbar \& Skinner, 1931

Pseudofuslina cfr. japonica (GüMBEL)

Pl. V, figs, 6, 7

1883: Fusulina japonica Gümbri. Schwager; Carbonische Foraminiferen aus China und Japan. China, Vol. IV, pp. 121-124, Pl. XV, figs. 1-11.

1925. Schellwienia japonica Ozawa. Paleontological Studies on the Limestone of Nagato. Jour. Coll. Sci. Imp. Univ. Tokyo, Vol. XLIV, Art. 6, p. 30.

1927. Schellwienia japonica Ozawa. Stratigraphical Studes of the Fusulina Limestone of Akasaka. Jour. Fac. Sci. Imp. Univ. Tokyo, Vol. II. Pt. 3, pp. 147-149, Pl. XXXVI, Pl. XXXVII fig. 7a.

1927. Schellwienia japonica L ве. Fusulinidae of North China. Paleontologia Sinica, Ser. B, Vol. IV, Fasc. 1, pp. 82-85, PI. XIII, figs. 1-8.

1934. Pseudofusulina japonica CHEN. Fusulinidae of South China. Paleontologia Sinica, Ser. B. Vol. IV, Fasc. 2, pp. 81, 82, Pl. VI, figs. 1, 9, Pl. VIII, fig. 7.

1936. Pseudofusulina japonica Нuzıмото. Paleontological Studies of the Titibu System of the Kwanto Mountainland. Sci. Rep. Tokyo Bunrika Daigaku, Sec. C, Vol. I, No. 2, pp. 56-59, Pl. V, figs. 8-10, Pl. VI, fig. 3.

Specimens here referred to Parafusulina cfr. japonica (GümвEL) have been obtained from several localities. Most of them, however, are poorly oriented and badly preserved. I am illustrating, for the sake of completeness, a few sagittal sections of this form. No axial section is available for illustration.

This species has been described in detail by many previous authors to which I need to add no more, because the materials at hand are not sufficient for discussion. The following description is based on the specimens at my disposal.

Shell short fusiform, with bluntly pointed poles. Number of volutions 4 to 6 . Axial length and median width are approximately $8.2 \mathrm{~mm}$ and $2.8 \mathrm{~mm}$, respectively.

The proloculus is spherical and is rather large. Its outside diameter is 420 microns in average for four specimens. Shell expands moderately. The average radius vectors of the first to the fifth volution are $0.34,0.56,0.81,1.12$, and $1.43 \mathrm{~mm}$, respectively.

The spirotheca consists of a tectum and a keriotheca. Average 
thicknesses of the spirotheca of the first to the fifth volution are $44,56,73,89$, and 112 microns, respectively.

Septa are thin and are rather regularly and intensely fluted throughout the length of the shell. Septal counts in the third and the fourth volution are $18 ?-21$ and $20 ?-27$, respectively. No chomata and phrenotheca are observed.

Locality and Horizon-..- As this species has been found from both Pseudoschwagerina- and Yabeina-limestones, the stratigraphic range of this species is considered to be wide. Five localities are known; 1) Loc. 172, Kabayamazawa, Setamai-mura, associated with Parafusulina cfr. kattaensis (Schwager) and P. sp.; 2) Loc. 2025, Kabayamazawa, Setamai-mura, with Parafusulina cfr. gigantea (Deprat) ; 3) Loc. 175, Kanokurazawa, Setamai-mura, with Waeringella? sp. Nipponitella sp. Schwagerina cfr. guembeli var. pseudoregularis Dunbar and SkInNer, Schwagerina sp. B, and Parafusulina cfr. wanneri (Schuber'T); 4) Loc. 1324, north of Shimizu, Setamai-mura, with Parafusulina sp. and 5) Loc. 1720, south of Omata, Yahagi-mura, with Parafusulina sp.

Pseudofusulina cfr. vulgaris var. watanabei (OzAwa em. LEE)

$$
\text { P1. V, figs. 8-12 }
$$

1923. Fuslina watarabei Ozawa. On some species of Fusulina, Honan, China. Jap. Jour. Geol. Geogr. Vol. II, No. 2, p. 38, figs. 1a-b.

1927. Schellwienia valgaris var. watanabei Lef. Fusulinidae of North China. Paleontologia Sinica, Ser. B, VoI. IV, Fasc. 1, pp. 64-66, Pl. IX, flgs. 4, 8.

1934. Pseudofusulina vulgaris var. watanabei $\mathrm{C}_{\mathrm{HFN}}$. Fusulinidae of South China. Paleontologia Sinica, Ser. B, Vol. IV, Fasc. 2, pp. 68-70, Pl. V, fig. 11, Pl. VIII, figs. $1-6,8$.

Shell short fusiform, considerably vaulted in the median part with very gently convex to slightly concave lateral slopes and moderately pointed poles. Number of volutions 4 or 5 . Axial length and median width are about $5.6 \mathrm{~mm}$ and $2.6 \mathrm{~mm}$, respectively.

The proloculus is spheric, and is rather large, having an outside diameter ranging from 320 to 460 microns. Average of eight specimens is 400 microns. The wall of proloculus is moderate in thickness, attaining 40 microns or less. The shell expands rather rapidly and almost uniformly except in the first volution. The average radius vectors of the first to the fifth 
volution of ten specimens are $0.33,0.56,0.82,1.14$, and $1.44 \mathrm{~mm}$, respectively.

The spirotheca is composed of a tectum and a clear alveolar keriotheca. The average spirothecal thicknesses of the first to the fourth volution of six specimens are $34,55,73$, and 92 microns, respectively.

The septa are thin in the inner volutions, but in the outer ones they sometimes become slightly thick, coated by the secondary deposits. The septa are rather strongly fluted throughout the length of the shell. The average septal counts of the first to the fourth volution of four specimens are 17, 21, 25, and 30 , respectively.

Chomata develop weakly in the outer volutions. Tunnel angle is 34 degrees in the third volution. Phrenotheca are well developed in the outer volutions.

Remarks - At least more than ten specimens in the material seem to be referred to this species, although few of them are adequate for illustration. So far as my observation is concerned this form fairly well agrees with Pseudofusulina vulgaris var. watanabe $i$ which was originally described by Ozawa as Fusulina (Schellwienia) watanabei and was later emended by Lee as a variety of Schellwienia vulgaris. There is no important difference in the characters of the shell between Honan form and the present one, except that the former is a little larger in size. Ozawa's original form seems to have no phrenotheca which are well observable in the present form.

Many more and better specimens are needed for the final determination.

Locality and Horizon - This species has been obtained from Loc. 1345 of the Pseudoschwagerina-limestone of northwest of Kawaguchi, Setamai-mura, associated with Schwagerina cfr. guembeli var. pseudoregularis Dunbar and SkINNER and Schwagerina? sp. A.

\section{Pseudofusulina? sp.}

$$
\text { Pl. VI, fig. } 1
$$

One specimen of Pseudofusulina has been obtained from the Pseudoschwagerina-limestone of Kanokurazawa. It is regrettable 
that I have been unable to find any well-oriented section except one oblique section which is illustrated in the plate.

Shell is large, attaining a width at least $5 \mathrm{~mm}$ or more. Number of volutions is 5 or more. Volution expands very rapidly and uniformly. Radius vectors of the first to the fifth volution of this specimen are 0.44 ?, $0.85,1.44,2.07$, and $2.62 \mathrm{~mm}$, respectively.

The spirotheca is composed of a tectum and a coarsely alveolar keriotheca. The thiaknesses of spirotheca of the second to the fifth volution are 133, 163, 153 and 184 microns, respectively.

The septa are also thick and seem to be rather strongly fluted. Phrenotheca are well developed. Other characteristics unknown.

Remarks - As far as the large size of the shell and very thick spirotheca are concerned, this form resembles Pseudofusulina vulgaris (Schellwien). Ps. turgida (Thompson and WheEler) from California has almost same rate of growth, but the spirotheca is much thinner.

Because of the extreme insufficiency of the material and the poor state of preservation I hold even the generic identification as tentative.

Locality and Horion — This species has been collected from Loc. 185 of Kanokurazawa, Setamai-mura, associated with Lepidolina? gigantea Toriyama, Lepidolina? sp. B and C.

Although the horizon from which the present species obtained was designated Pseudoschwagerina-horizon by Minato*, it should be assigned to Yabeina-horizon, because it contains no charcteristic species of Pseudoschwagerina-horizon, but only species of the Yabeina-horizon as described above.

SubFamily VERBEEKININAE

Genus PSEUdOdOLIOLINA Yabe \& Hanzawa, 1932

Pseudodoliolina? sp.

PI. VI, fig. 2

Very doubtful specimens which may probably be assigned to the genus Pseudodoliolina have been found in the Yabeina-limestone of Katchizawa. As they are preserved in imperfect condition,

* See foot-note of p. 128 
destroyed, and not well-oriented, I have only observed the following features.

Shell seems to have short cylindrical or subspherical shape, with much rounded ends. Diameter of shell is rather small, attaining a diameter of about 1.5-1.8 $\mathrm{mm}$. The number of volutions is at least 6 or more. The spirotheca seem to consist of a single homogenous layer in which no minute structure can be observed. Spirothecal thickness is 23 microns in the inner volutions and 47 microns in the outer ones. Septa almost plane throughout shell. Parachomata well developed.

Locality and Horizon - This species has been found in the Loc. 247 of Katchizawa, Setamai-mura, associated with Staffella yobarensis Ozawa which was described in the Upper Permian of Akiyoshi Limstone.

\section{Subfamily NEOSCHWAGERININAE \\ GeNus LEPIDOLINA LeE, 1933 \\ Lepidolina? sp. A \\ Pl. VI, fig. 4}

Few specimens of Lepidolina? sp. A have been obtained from the Yabeina-limestone of Kanokurazawa and Katchizawa. Although almost all of them are so poorly preserved, deformed after fossilization, or improperly oriented that they are not adequate for giving full description and illustration of the species, I illustrate only one of them for the sake of the completeness of this study.

Shell is short fusiform with much vaulted median portion, nearly flat lateral slopes and obtuse polar regions. It is almost hard to determine the original dimensions of the shell, because it is deformed along the direction almost parallel to the median diameter. Illustrated para-axial section of 13 volutions has a length of approximately $7 \mathrm{~mm}$ and a median width of $8.3 \mathrm{~mm}$ as it is. Measured radius vectors of the first to the thirteenth volution of this specimen are $0.18,0.37,0.55,0.74,0.92,1.11,1.29$, $1.48,1.78,2.32,3.06$ ?, 3.58 ?, and 4.17 ? mm, respectively.

The spirotheca is thin, generally not over 40 microns thick if the secondary deposits on the spirotheca are omitted. The spirotheca seems to be composed of a tectum and obscure translucent layer. In spite of careful observation on the spirotheca 
under high magnification of microscope, no alveolar structure of the latter has been detected.

As there is no sagittal section in the present collection it cannot be determined what and how many axial septula develop between each pair of septa. The primary spiral septula are well developed. They are in contact with the top of the parachomata which are rather poorly developed as a neoschwagerinid. In the inner volutions the lower edges of the primary spiral septula are not of a pendant shape, but sometimes there is more or less swelling in the middle portion of them probably due to the secondary deposits. In the outer volutions the primary spiral septula are slender and almost uniform in thickness.

There is no secondary spiral septula between each pair of the primary spiral ones in the inner four volutions. Outward from the fifth volution to the last one, one or at most two secondary spiral septula are introduced between each pair of adjacent primary spiral septula. The secondary spiral septula are primitive and rather short, free ends of them are not swelling. Parachomata poorly developed.

The size and the shape of the proloculus are not determined. Remarks - As regards the spirothecal structure of this form I have not been sure whether the absence of keriothecal structure is due to its original character or to the imperfect condition of preservation. However, it seems that the former is the case, because I have been able to recognize the alveolar structure of the spirotheca in a schwagerinid shell contained in the slide made of the same limestone in which the present form is contained.

In the shape of the shell, the structure of the spirotheca, and the arrangements of two kinds of the spiral septula, this form may be referable to the geus Lepidolina LEE, although there are some discrepancies among many paleontologists as to the validity of this genus.

Further study of this form will be necessary before a definite generic assignment can be made.

Locality and Horizon - This species has been found in the Yabeina-limestone of the following three localities as 1) Loc. 188, Kanokurazawa, Setamai-mura, associated with Lepidolina? sp. B and C ; 2) Loc. 240, Katchizawa, Setamai-mura, with Schwagerina sp. indet.; and 3) Loc. 302, Katchizawa, Setamai-mura, with Mille- 
rella? sp., Schwagerina douvillei (ColAnI), Parafusulina cfr. wanneri (Schubert), Pseudofusulina sp., Lepidolina? sp. B, C, and D.

\section{Lepidolina? sp. B}

Pl. VI, fig. 5, Pl. VII, fig. 1

Shell large ellipsoidal or fusiform with bulged median portion, gently convex to slightly concave lateral slopes and rounded polar extremities. A shell of 13 volutions attains a length of $10.5 \mathrm{~mm}$ and a width of $5.5 \mathrm{~mm}$. Number of volutions is 10 to 13 .

The proloculus is very large and almost spheric, having an outside diameter ranging from 580 to 680 microns. The wall of proloculus is very thin, attaining a thickness of less than 30 microns. The shell expands rather rapidly. Radius vectors of the first to the thirteenth volution average $0.42,0.56,0.68,0.84,0.99$, $1.15,1.32,1.50,1.69,1.88,2.11,2.37$, and $2.64 \mathrm{~mm}$, respectively, in four specimens.

The spirotheca seems to be composed of a compact single layer in which no alveolar structure has been observed. However, I have been unable to determine whether the absence of the alveolar keriotheca in the spirotheca is due to its original structure or to the unfavourable condition of the preservation.

Septa are thin and are slightly irregular in length. Because of the absence of a well-oriented sagittal section I have not been able to understand how many axial septula are present between adjacent septa in the inner volutions, but I have observed in an excentric section that axial septula of 3 to 5 intercalate between each pair of adjacent septa in the outer volutions. The secondary spiral septula of 1 to 3 in number occur between adjacent primary spiral septula in the outer volutions, but are generally absent in the inner ones. All septula are not equal in length. They are very thin near their junction with the spirotheca, but their free ends are considerably thickened, sometimes taking club-shap in cross section.

Remarks - So far as the external form of shell, large size of the proloculus and the arrangement and characters of septula are concerned, the present form may be a new species of Lepidolina?. However, not enough information is available from the materials at hand for establishing a new species. As described above, I do 
not feel certain that the absence of the alveolar structure in the spirotheca of this form is due to the original character of this form or not.

Sufficient and better specimens will be needed before a definite generic assignment can be made.

Locality and Horizon - This species occurs in the Pseudoschwagerina-limestone of Kanokurazawa (Loc. 185) and in the Yabeinalimestone of Kanokurazawa (Loc. 188 and Loc. 254), Setamaimura ; Katchizawa (Loc. 302). Setamai-mura, and east of Omata (Loc. 2008). In Loc. 185 it associates with. Pseudofulina sp., Lepidolina? gigantea TorIyAma and Lepidolin? sp. C ; in Loc. 188, with Lepidolina? sp. A and C; in Loc. 254, with Lepidolina? sp. $\mathrm{C}$; in Loc. 302, with Millerella? sp., Schwagerina douvillei (ColANI), Parafusulina cfr. wanneri (Schubert), Pseudofuslina sp., and Lepidolina? sp. A, C, and D; and in Loc. 2008, with Schwagerina? sp. indet

\section{Lepidolina? sp. C}

\section{Pl. VII, figs. 2-5}

An elongate fusiform species of 9 to 13 volutions, attaining a length of 13.5 to $15.0 \mathrm{~mm}$ and a width of about $3.7 \mathrm{~mm}$. The polar ends are bluntly rounded.

The proloculus is large and spheric. Its outside diameter is ranging from 360 to 620 microns, averaging 460 microns in ten specimens. The wall of the proloculus is very thin, attaining a thickness of less than 15 microns.

The first few volutions are rather subspheric in form, and then the axial length increases very rapidly as shell grows, attaining a form ratio of 3.6 to 4.5 in maturity. The average radius vectors of the first to the tenth volution in ten specimens are $0,31,0.40,0.50,0.60,0.70,0.82,0.96,1.10,1.25$, and $1.38 \mathrm{~mm}$, respectively.

The spirotheca is thin and seems to consist of only a single layer in which no alveolar structure is discernible even under high magnification of microscope.

Septa are thin and slightly irregular in length. The lowermost surface of the septa generally bends forward, contacting with the preceeding volution at a low angle. One to three axial septula 
are generally intercalated between two adjacent septa in the inner volutions, and three to six in the outer ones. The primary spiral septula are present throughout the shell. One or two secondary spiral septula occur between the adjacent primary spiral septula in the outer volutions. They are short and rather irregular in length. Their free ends are considerably thickened, representing club-shapes.

Remarks - As well as the foregoing one, this form may be a new species of Lepidolina?, in having much slender fusiform and very large proloculus. However, materials at my disposal are too poorly preserved and too much deformed to establish a new species. Furthermore, I am not certain even of the generic assignment of this species.

More sufficient and better specimens will be necessary before a definite generic assignment and full specific description can be made.

Locality and Horizon — This species has been found in the Pseudoschwagerina-limestone of Kanokurazawa (Loc. 185), and in the Yabeina-limestone of Kanokurazawa (Loc. 188 and 254) and Katchizawa (Loc. 302), all in Setamai-mura. I have already pointed out a doubt about the stratigraphic position of the Pseudoschwagerina-limestone of Loc. 185.

Associated species are as follows; Pseudofusulina sp., Lepidolina? gigantea ToRIyAmA, and Lepidolina? sp. B in Loc. 185; Lepidolina? sp. A and B in Loc. 188; Lepidolina? sp. B in Loc. 254; Millerella? sp., Schwagerina douvillei (CoLANI), Parafusulina cfr. wanneri (SснивеRт), Pseudofusulina sp., Lepidolina? sp. A, B, and D in Loc. 302.

\section{Lepidolina? sp. D \\ Pl. VII, fig. 6}

In the Yabeina-limestone of Katchizawa one large specimen of. Lepidolina? has been found which differs considerably from Lepidolina? spp. described above. Although the section of this form is an axial one, both polar regions were destroyed. Following description is based on this half broken specimen.

Shell is large, attaining a width of about $7 \mathrm{~mm}$. Proloculus is very large, having an outside diameter of 660 microns. Its 
wall is very thin and is 47 microns in thickness. Shell expands rather rapidly. Radius vectors of the second, the fourth to the thirteenth volution are $0.63,0.92,1.11,1.33,1.55,1.81,2.03,2.27$, $2.51,2.88$, and $3.56 \mathrm{~mm}$, respectively.

Arrangement and character of septa and axial septula are unknown. Primary spiral septula present throughout shell. Secondary spiral septula seem to be undeveloped in the inner volutions. One or two secondary spiral septula occur between primary spiral septula in the outer volutions. They are short and are not equal in length.

Remarks - As far as the size of the proloculus and the rate of growth are concerned this form more or less agrees with Yabeina (Lepidolina) hayasakai Ozawa. However, the latter species has a much vaulted fusiform having a form ratio of only 1.4, while this form, although deformed and prolonged, might have had a rather slender fusiform.

More sufficient and better specimens are needed to determine the species.

Locality and Horizon - This species has been obtained in the Loc. 302 of the Yabeina-limestone of Katchizawa, Setamai-mura, associated with Millerella? sp., Schwagerina douvillei (CoLANI), Parafusulina cfr. wanneri (Schubert), Pseudofusulina sp., and Lepidolina? sp. A, B, and C. 


\section{REFERENCES}

Minato, M., 1942. Unconformity of the Pre-Sakamotozawa Stage (Pre-Sakmarian) in the Kitakami Mountainland, Northeast Japan: Jour. Geol. Soc. Japan, Vol. 49, No. 581, pp. 47-72 (Japanese with English resume)

, 1944A. Stratigraphische Gliederung des Perm des Süd-Kitakami-Gebirges, Japan. Jour. Geol. Soc. Japan, Vol. 51, No. 606, pp. 83-90 (Japanese, with German resume)

, 1944B. Stratigraphische Stellung der Usuginu-Konglomerate, mit besonderer Berücksichtung des Toyoma-Meeres, eines Binnenmeeres des späteren Permischen Zeit im Kitakami-Gebirge, Japan: Jour. Geol. Soc. Japan, Vol. 51, No. 609, pp. 169-186 (Japanese, with German resume)

, 1944C. Phasenanalyse der Gebirgsbildungen der paleozoischen Area in Kitakami-Gebirge (nordöstrisches Honsyu, Japan): Stratigraphische und tektonische Untersuchungen des japanischen Paleozoikums, Teil I. Japanese Jour. Geol. Geogr. Vol. XIX, Nos. 1-4; pp. 151-180. (German)

Toriyama, R., 1947. On Fusulinid Fossils from the Kitakami Mountainland: Jour. Geol. Soc. Japan, Vol. 53, Nos. 622-627, pp. 112-113 (Japanese, with fossil list) , Gigantic Fusulinid Species from the Kitakami Mountainland, Northeastern Japan. Jour. Paleontology. (in printing) 


\section{EXPLANATION OF PLATE III}

All figures are $\times 10$, except figs. 1 and 2 .

Fig. 1. Millerella? sp. $\quad \ldots \begin{array}{lllllllllllll} & \ldots & \ldots & \ldots & \ldots & \ldots & \ldots & \ldots & \ldots & \ldots & \ldots & \ldots & \text { p. } 129\end{array}$

Axial section (302-1d). $\times 40$

2. Staffella yobarensis Ozawa...

Axial section $(247, d) . \times 20$

3, 4. Waeringella? sp. ...

3, para-axial section (175-5d); 4, diagonal section (175-3b).

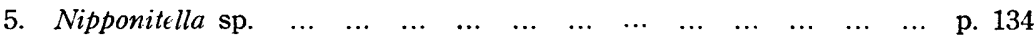

Axial section, having a part of inflated marginal flange (175-4).

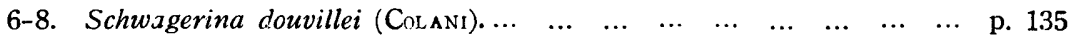

6 , axial section $(302-1 a) ; 7$, sagittal section (more or less diagonal) (302-1c); 8, diagonal section (302-1e).

9,10. Schwagerina cfr. guembeli var. pseudoregularis DunBAR and SKInNer. p. 136 9, axial section (slightly tangential) (1345-1b); 10, diagonal section (1345-2c).

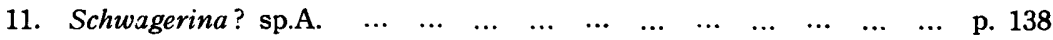

Axial section (1345-4).

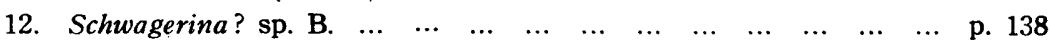

Axial section (175-2c). 
Plate III
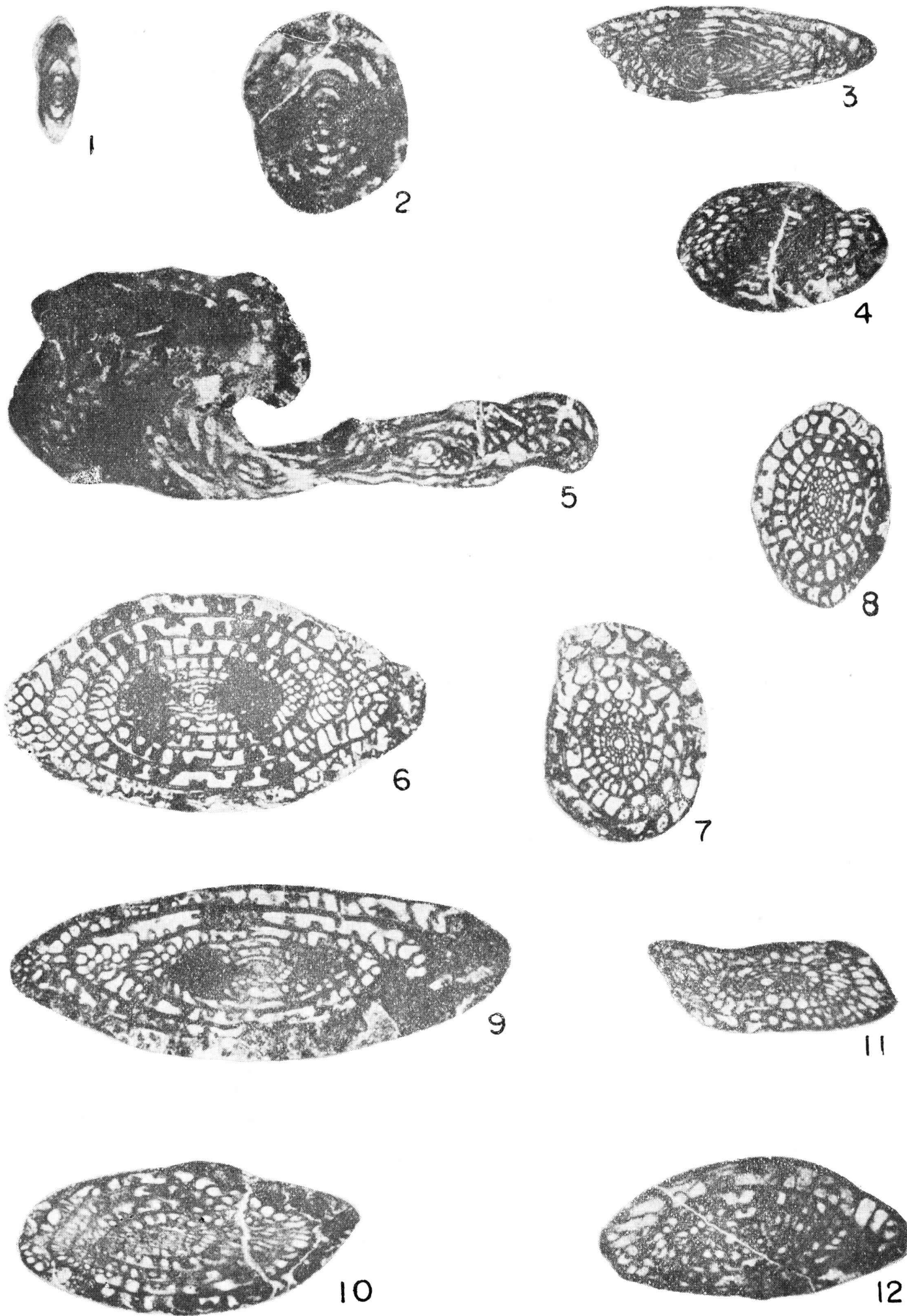


\section{EXPLANATION OF PLATE IV}

All figures are $\times 10$.

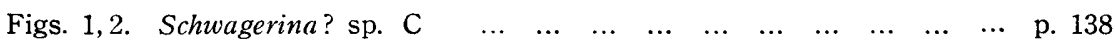

1 , tangential section (2276); 2 , excentric section (252-1).

$\begin{array}{lllllllllllll}\text { 3. Pseudoschwagerina? } & \text { sp. } & \ldots & \ldots & \ldots & \ldots & \ldots & \ldots & \ldots & \ldots & \ldots & \ldots & \text { p. } 140\end{array}$

Excentric section (377).

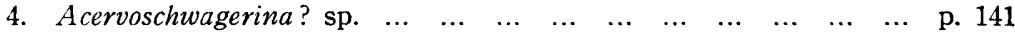

Sagittal section (528-1).

5,6. Parafusulina cfr. kattaensis (SCHWAGER)

5 , tangential section (172-3); 6, excentric section (1407-1a). 
Plate IV
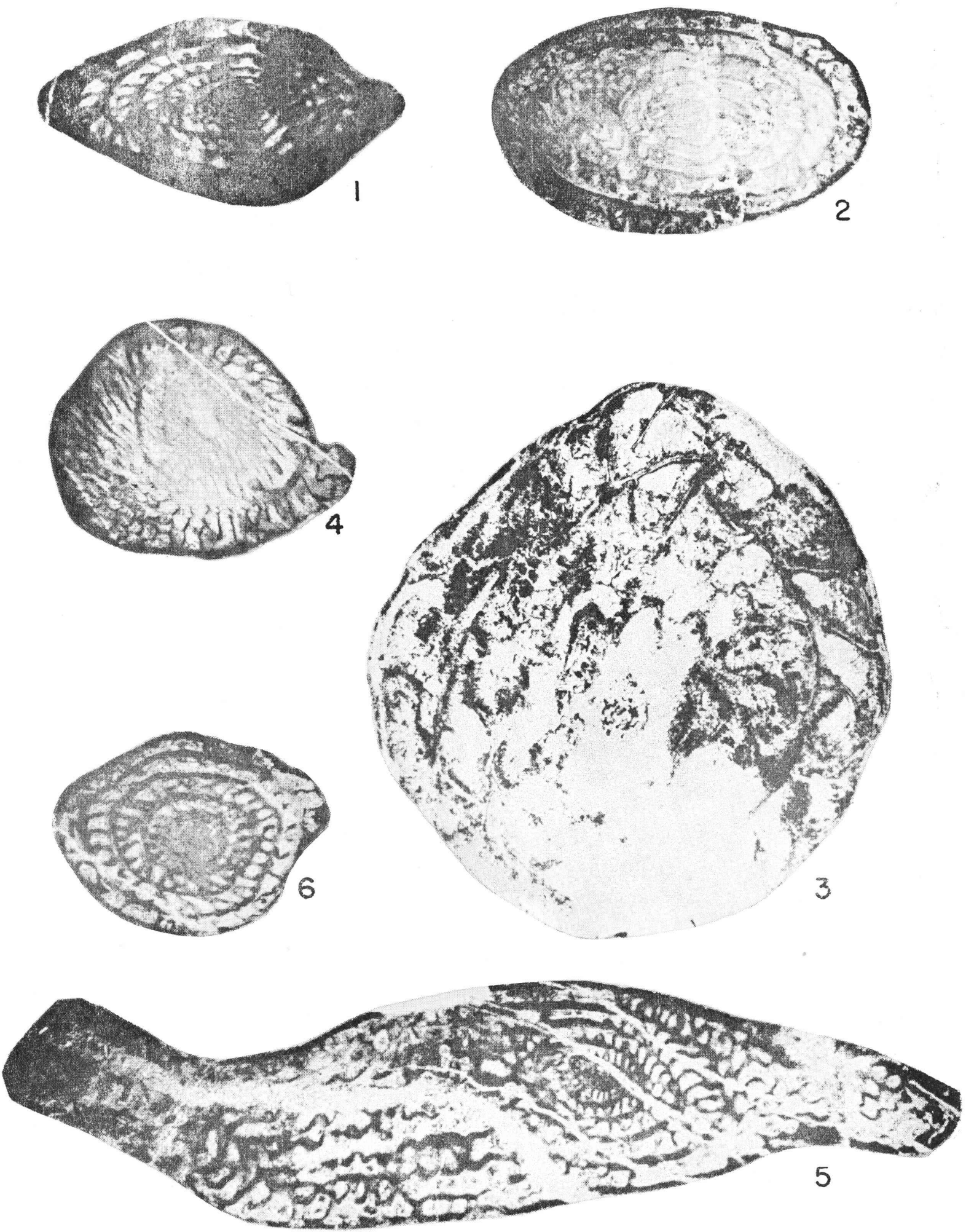


\section{EXPLANATION OF PLATE V}

All figures are $\times 10$.

Figs. 1. Parafusulina cfr. kattaensis (ScrWAGER) Tangeatial section (1407-1c).

2. Parafusulina cfr. wanneri (SchubrRT) Tangential section $(235, \mathrm{c})$.

3, 4. Parafusulina cfr. gigantea (Deprat) 3 , excentric section $(2025$, a); 4, sagittal section of the immature specimen $(1277, \mathrm{~b})$.

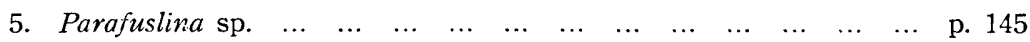
Axial section (252-2a).

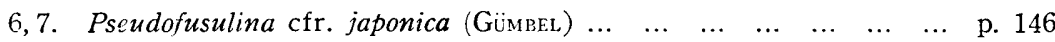
Sagittal sections (1324-1a and 2025, b).

8-12. Pseudofusulina cfr. vulgaris var. watanabei (Ozawa em. LEE) ... $\quad$ p. 147 8,9 , axial sections $(1345-1 \mathrm{e}$ and $1 \mathrm{~g}):, 10-12$, sagittal sections (1345-1f, 1d, and 2b). 
Plate V

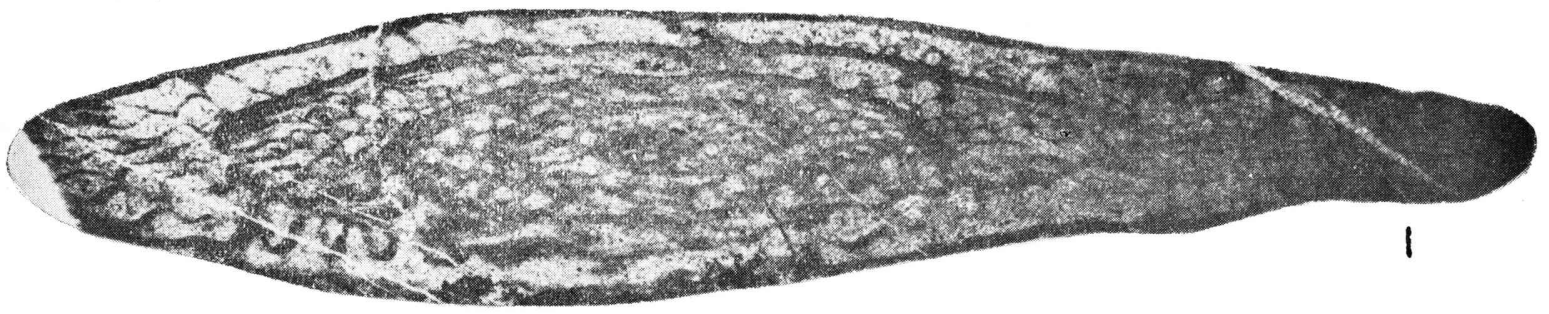

C.
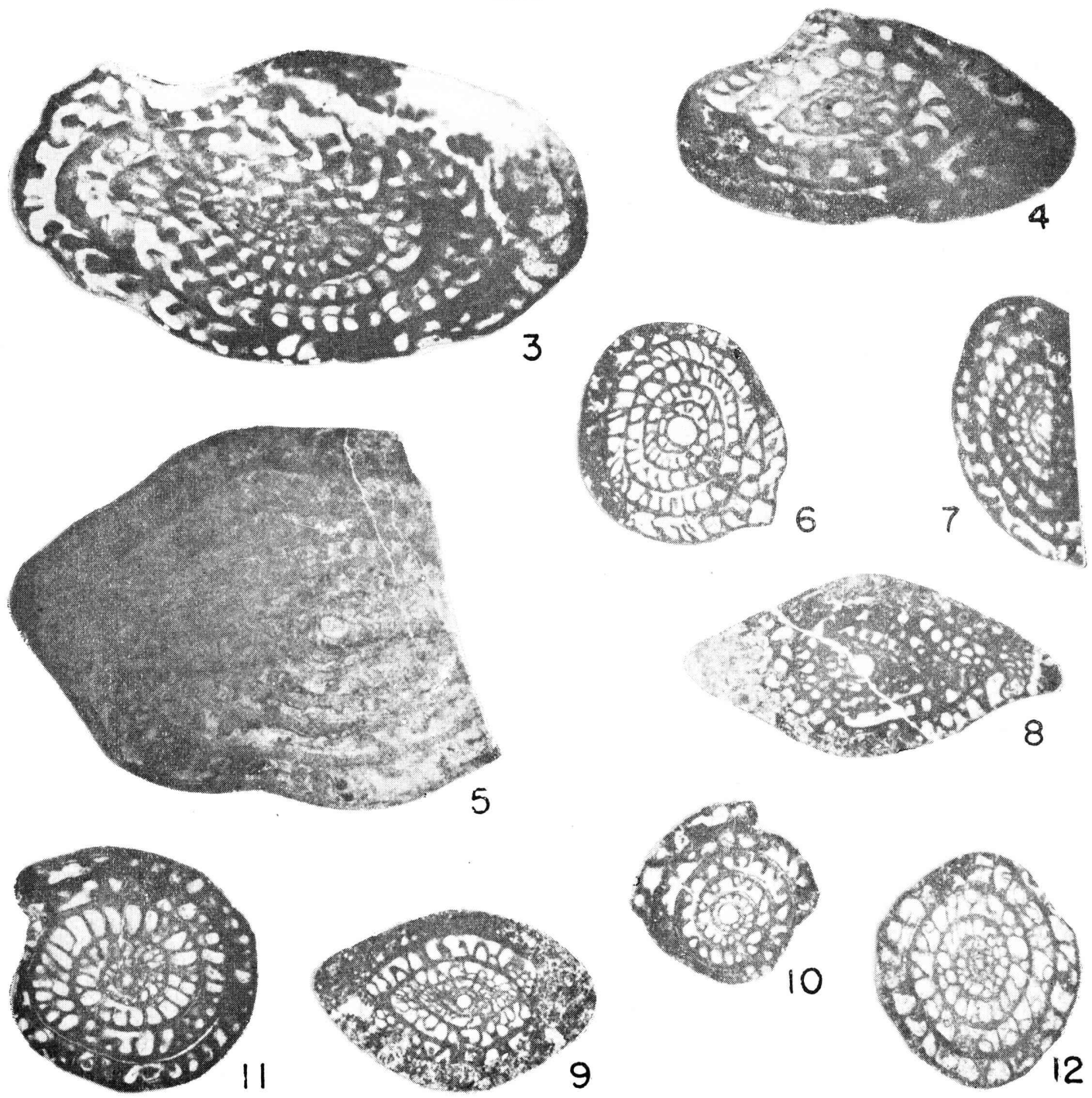


\section{EXPLANATION OF PLATE VI}

All figures are $\times 10$, except fig. 3 .

Figs. 1. Pseudofulina? sp. $\begin{array}{lllllllllllll} & \ldots & \ldots & \ldots & \ldots & \ldots & \ldots & \ldots & \ldots & \ldots & \ldots & \ldots & \text { p. } 148\end{array}$

Tangential section (185-8).

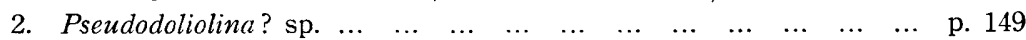

Excentric section of broken specimen (247).

3. Lepidolina? gigantea TоR IYAMA.

Tangential section of the holotype (185-3b), illustrated for convenience's sake. $\times 5$.

4. Lepidolina? sp. A $\quad \ldots \begin{array}{llllllllllll} & \ldots & \ldots & \ldots & \ldots & \ldots & \ldots & \ldots & \ldots & \ldots & \ldots & \text { p. } 150\end{array}$ Axial section (240-1).

$\begin{array}{lllllllllllllll}\text { 5. Lepidolina? sp. } & \text { B } & \ldots & \ldots & \ldots & \ldots & \ldots & \ldots & \ldots & \ldots & \ldots & \ldots & \ldots & \text { p. } 152\end{array}$

Axial section (185-1a). 

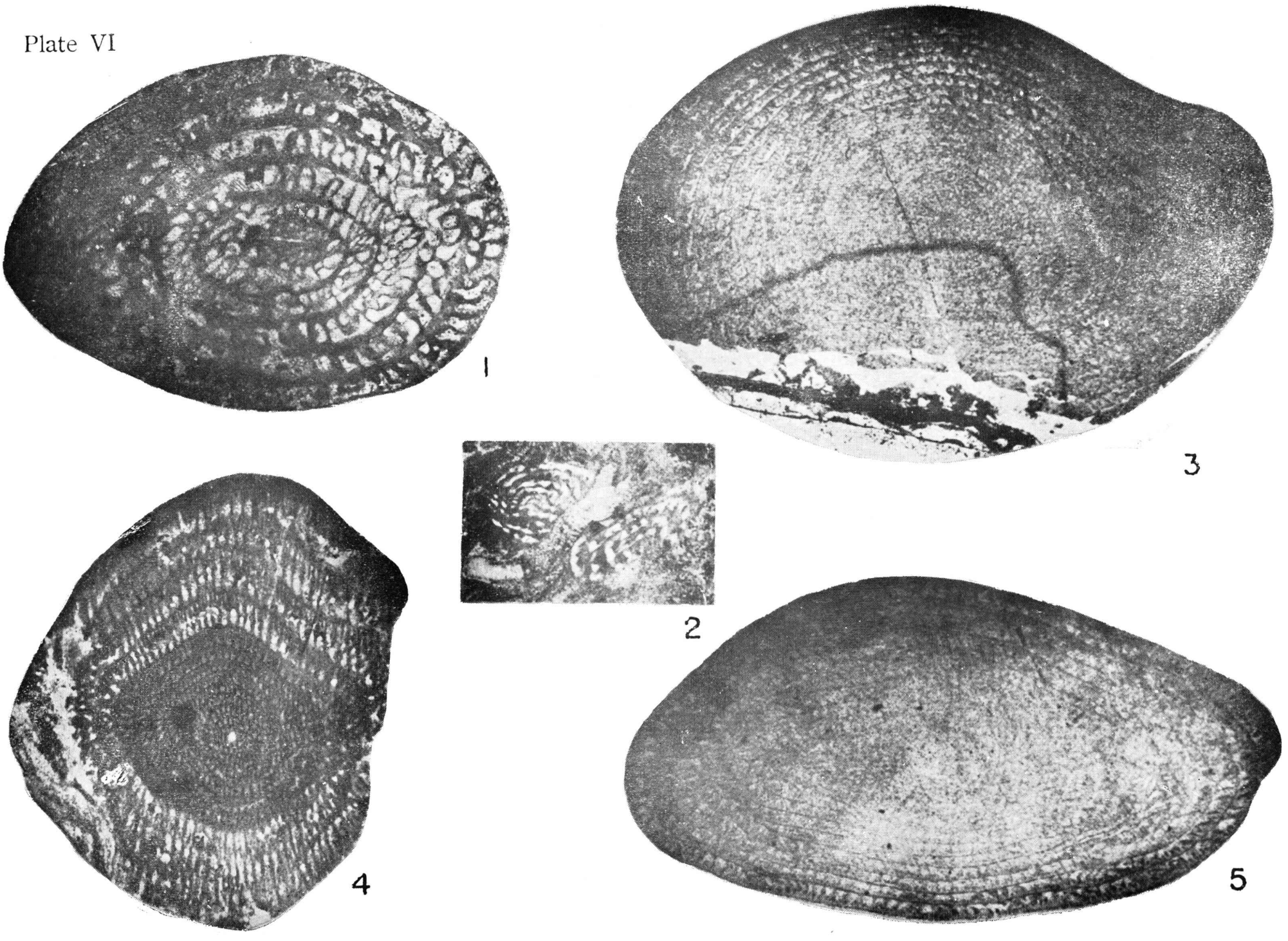


\section{EXPLANATION OF PLATE VII}

All figures are $\times 10$

Figs. 1. Lepidolina? sp. B $\quad \ldots \begin{array}{llllllllllll} & \ldots & \ldots & \ldots & \ldots & \ldots & \ldots & \ldots & \ldots & \ldots & \ldots & \text { p. } 152\end{array}$ Axial section (185-1b).

2-5. Lepidolina? sp. $\mathrm{C}$. . $2-4$, axial sections $(185-6 a, 302-6$, and $254-2 a) ; 5$, sagittal section (185-2b).

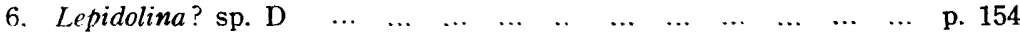

Axial section (302-4). 

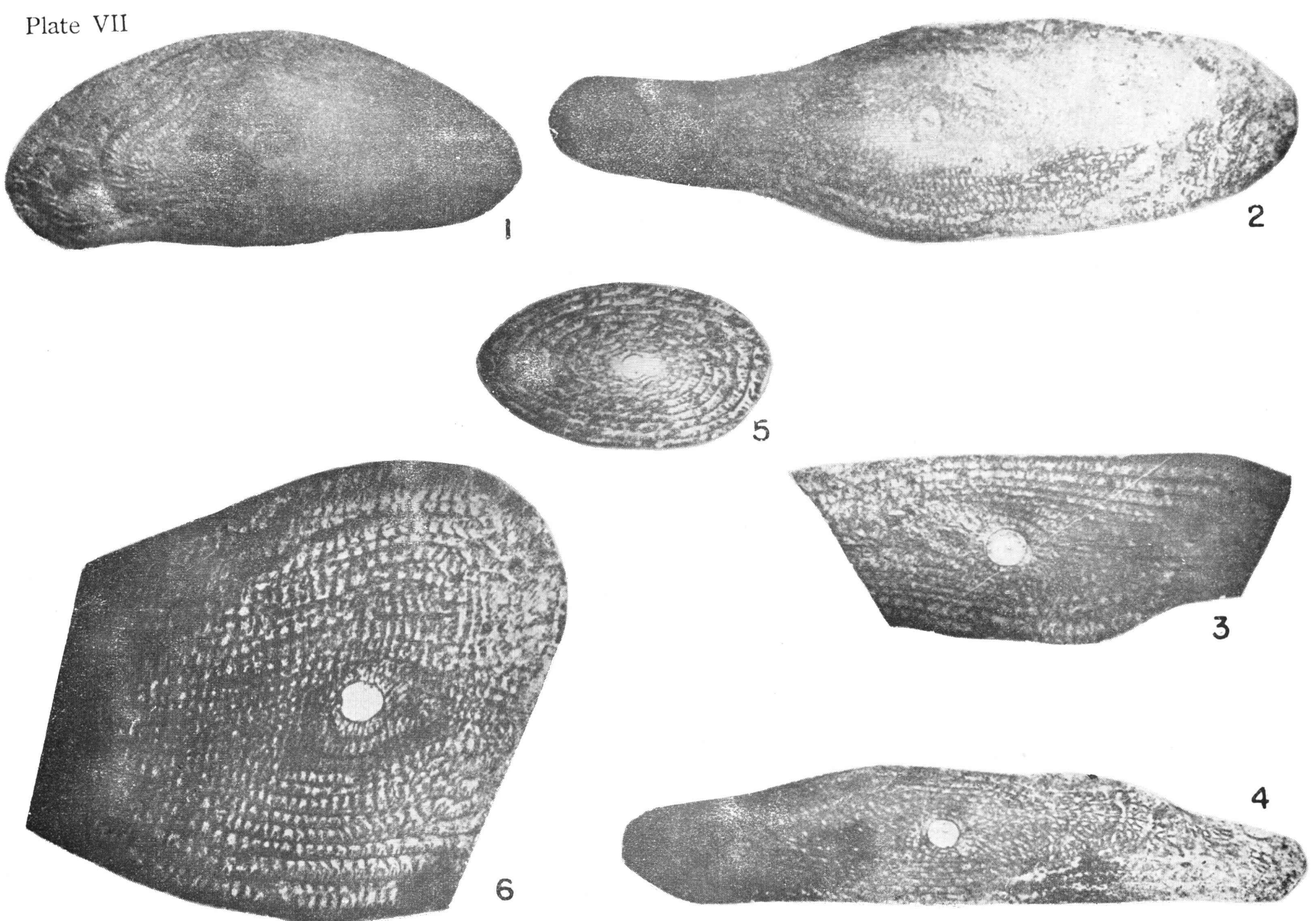